\begin{tabular}{|c|c|}
\hline \multirow{3}{*}{ 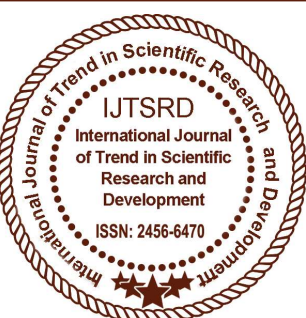 } & $\begin{array}{l}\text { International Journal of Trend in Scientific } \\
\text { Research and Development (IJTSRD) }\end{array}$ \\
\hline & International Open Access Journal \\
\hline & ISSN No: 2456 - 6470 | www.ijtsrd.com | Volume - 2 | Issue - 5 \\
\hline
\end{tabular}

\title{
Quality Assessment of Water in Municipal Solid Waste Dumpsite Area
}

\author{
Khin Win ${ }^{1}$, Ni Ni Win ${ }^{2}$ \\ ${ }^{1}$ Lecturer, ${ }^{2}$ Undergraduate Student \\ Civil Engineering Department, Yangon Technological University, \\ Yangon, Myanmar
}

\begin{abstract}
The focus of this study is to assess the contribution of waste dumping in water pollution. Water samples were collected from the nearby Htein Pin open dumping site in Yangon, lake, tube wells, river and leach ate were analyzed and observed contamination. It has been found that most of the parameters of water are not in the acceptable limit in accordance with the WHO drinking guide lines. It is concluded that the contamination is due to the solid waste that are dumped in the area.
\end{abstract}

Keywords: Water Sample, Open-dumping site, Solid waste, Contamination

\section{INTRODUCTION}

Solid waste disposal creates a problem primarily in highly populated areas. The more concentrated the population, the greater the problem becomes [6]. Inadequate Solid Waste Management Services adversely affect the environment, causing water, land and air pollution, and will ultimately resultants in ill effects on human health.

Most of the developing countries use open dumping to dispose of wastes. Indiscriminate dumping of wastes contaminates surface and ground water supplies. Unscientifically managed dumping yards are prone to ground water contamination because of leachate production. Leachate is the liquid that seeps from solid wastes or other medium and have extracts with dissolved or suspended materials from it.

The Solid Waste Management in Yangon consists mainly of the collection and disposal system, and is the responsibility of the YCDC. Collected waste are directly transported to the suburban districts and dumped into the low-lying land.

\section{STUDY AREA}

Htein Pin is one of the existing open dumping site in Yangon City. In 2001, YCDC used the land disposal site in HlaingTharyar Township named Northern Final Disposal Site, "Htein Pin."

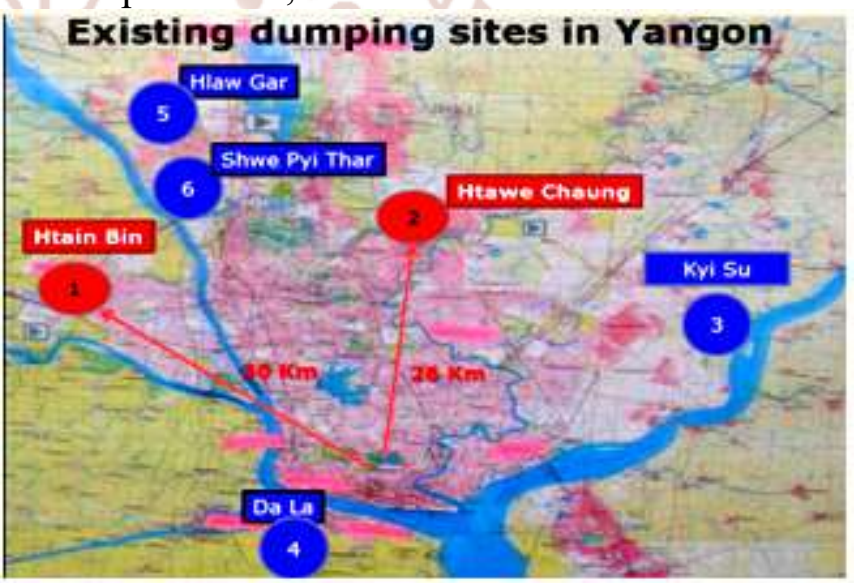

Figure 1- Existing dumping sites in Yangon Source: YCDC, 2017

This dmping site is located on the other side of the Hlaing River at a distance of about $26 \mathrm{~km}$ from downtown area. It is a flat area with high water table and even subjected to flooding during the rainy season. The whole area is 300 acres and usage area about 150 acres, allowable capacity is three million tons, use the 15 years.

Htein Pin Final Disposa Site is disposed by north district in eight townships, west district in ten townships, five markets and HlaingTharYar Industrial zone. Therefore common disposal wastes are kitchen wastes, industrial wastes and market wastes. The 
disposal of solid waste amount is currently 1000-1100 tons per day.

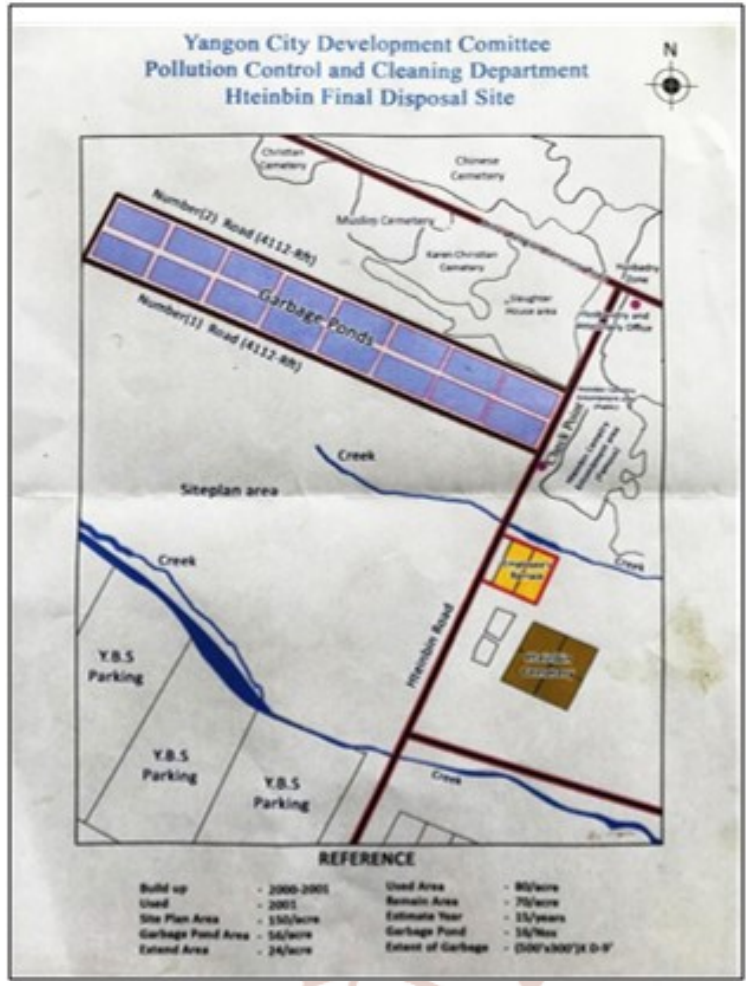

Figure 2 - Map of study area Source: YCDC

\section{III.Literature Review}

\section{A. Summary of Solid Waste}

Solid Wastes are also defined as "all the wastes arising from human and animal activities that /are normally solid and are discarded as useless or unwanted" [2].

\section{B. Solid Waste Management}

Solid Waste Management may be defined as the discipline associated with the control of generation, storage, collection, transfer and transport, processing and disposal of solid wastes in a manner that is in accord with the best principles of public health, economics, engineering, conservation, aesthetics, and other environmental considerations, and that is also responsive to public attitudes.

\section{Source of Solid Waste}

Sources of solid waste in a community are, in general, related to land use and zoning. Those sources are residential, commercial, institutional, construction and demolition, municipal services, treatment plant sites, industrial and agricultural.

The sources and quantities of solid waste depend on various factors such as economics, culture, heritage, industrialization, and season [2].
D. Factors That Affect Waste Generation Rate

Solid waste generation rates vary depending upon many factors which can be categorized as: source reduction, recycling, activities, public attitudes and legislation, geographic location, characteristics of service area and season of year [3].

\section{E. Disposal}

Today, the disposal of waste by land filling or land spreading is the ultimate fate of all solid wastes, whether they are residential wastes collected and transported directly to a landfill site.

\section{Methodology}

In sanitary conditions of uncontrolled dumps are sources of health and environmental hazards through pathogenic organisms, insects, vermin, rodents, air and water pollution. The Fig. 3 describes the methodology of this study.

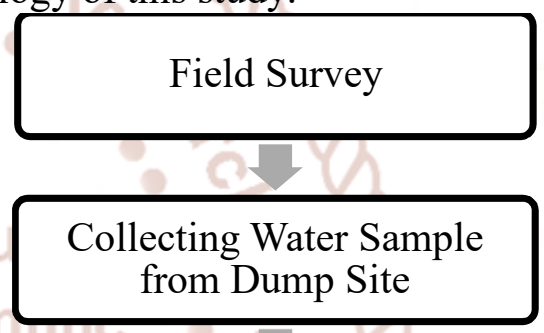

Water Quality Analysis of Dump Site

Figure 3-Flow chart of methodology

\section{A. Sampling and Analytical Method}

Since there is no proper solid waste treatment and disposal, at the dump site, there is a possibility of contamination of ground water around the site.

The analysis was done as per the standard methods. The physical and chemical parameters examined in water samples include $\mathrm{pH}$, color, turbidity, temperature, conductivity, total hardness, total alkalinity, carbonate, chloride, sulfate, suspended solid, dissolved solid, fluoride, ammonia, dissolved oxygen, BOD, COD, zinc, manganese, phosphate, arsenic, nitrate, total coliform. The results were compared with WHO drinking water guideline (Geneva, 1993).

\section{Results and Discussion}

Water samples were collected nearby open dumping site lake, river, tube well and leach ate, were analyzed at the ISO Tech laboratory, Yangon. The results were compared with WHO drinking water guideline. 
International Journal of Trend in Scientific Research and Development (IJTSRD) ISSN: 2456-6470

TABLE I. WATER QUALITY AROUND HTEINPIN FINAL DISPOSAL SITE

\begin{tabular}{|c|c|c|c|c|c|}
\hline Parameters & LW & RW & $T W^{a}$ & $\mathrm{TW}^{\mathrm{b}}$ & WHO \\
\hline $\mathrm{pH}$ & 7.3 & 8.1 & 8.0 & 7.2 & $6.5-8.5$ \\
\hline Color (TCU) & 15 & 80 & 5 & Nil & 15 \\
\hline $\begin{array}{c}\text { Temperature } \\
\left({ }^{\circ} \mathrm{C}\right)\end{array}$ & 25 & 25 & 25 & 25 & - \\
\hline $\begin{array}{l}\text { Turbidity } \\
\text { (NTU) }\end{array}$ & 16 & 130 & 20 & & \\
\hline $\begin{array}{l}\text { Conductivity } \\
\text { (micro S/cm) }\end{array}$ & 287 & & & & \\
\hline $\begin{array}{c}\text { Total } \\
\text { Hardness } \\
(\mathrm{mg} / \mathrm{l} \text { as } \\
\mathrm{CaCO}_{3} \text { ) }\end{array}$ & 48 & & & 510 & 500 \\
\hline $\begin{array}{c}\text { Total } \\
\text { alkalinity } \\
\text { (mg/l as } \\
\mathrm{CaCO}_{3} \text { ) }\end{array}$ & 72 & & 212 & 236 & \\
\hline $\begin{array}{l}\text { Phenol- } \\
\text { phthalein } \\
\text { alkalinity } \\
(\mathrm{mg} / \mathrm{l})\end{array}$ & Nil & & & - & - \\
\hline $\begin{array}{l}\text { Carbonate } \\
(\mathrm{mg} / \mathrm{l})\end{array}$ & Nil & Nil & & & $\odot$ \\
\hline $\begin{array}{l}\text { Chloride } \\
\text { (mg/l) }\end{array}$ & 41 & 880 & 940 & 800 & 250 \\
\hline $\begin{array}{l}\text { Sulphate } \\
(\mathrm{mg} / \mathrm{l})\end{array}$ & Nil & 42 & 42 & 22 & 200 \\
\hline $\begin{array}{c}\text { Suspended } \\
\text { solids (mg/l) }\end{array}$ & 32 & 110 & - & - & - \\
\hline $\begin{array}{c}\text { Dissolved } \\
\text { solids (mg/l) }\end{array}$ & 144 & 1792 & 1865 & 1498 & 1000 \\
\hline $\begin{array}{l}\text { Fluoride } \\
(\mathrm{mg} / \mathrm{l})\end{array}$ & 1.8 & 0.7 & 0.4 & 1.2 & 1.5 \\
\hline
\end{tabular}

TABLE I. CONTINUED

\begin{tabular}{|c|c|c|c|c|c|}
\hline Parameters & $\mathbf{L W}$ & RW & $T W^{a}$ & $\mathrm{TW}^{\mathrm{b}}$ & WHO \\
\hline $\begin{array}{c}\text { Ammonia } \\
(\mathrm{mg} / \mathrm{l})\end{array}$ & 0.22 & 10.1 & - & - & - \\
\hline DO (mg/l) & 3.2 & 2.8 & - & - & - \\
\hline BOD (mg/l) & 9 & 42 & - & - & - \\
\hline $\mathrm{COD}(\mathrm{mg} / \mathrm{l})$ & 32 & 96 & - & - & - \\
\hline Zinc $(\mathrm{mg} / \mathrm{l}$ & Nil & & - & - & - \\
\hline $\begin{array}{l}\text { Arsenic } \\
(\mathrm{mg} / \mathrm{l})\end{array}$ & & & 0.005 & 0.005 & 0.01 \\
\hline $\begin{array}{l}\text { Journ } \\
\text { Nitrate (mg/l) }\end{array}$ & 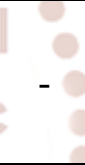 & 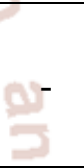 & 0.8 & 2.0 & 50 \\
\hline $\begin{array}{l}\text { Total } \\
\text { Coliform } \\
(\mathrm{CFU} / 100 \mathrm{ml})\end{array}$ & 30 & 0 & - & - & - \\
\hline Iron (mg/l) & & & 0.68 & 0.2 & 0.3 \\
\hline $\begin{array}{c}\text { Manganese } \\
(\mathrm{mg} / \mathrm{l})\end{array}$ & & - & 0.2 & 2.1 & 0.05 \\
\hline $\begin{array}{c}\text { Phosphate } \\
(\mathrm{mg} / \mathrm{l})\end{array}$ & - & - & Nil & Nil & - \\
\hline
\end{tabular}

Note: LW - Lake water

RW - River water

$\mathrm{TW}^{\mathrm{a}}$ - Tube well near solid waste

$\mathrm{TW}^{\mathrm{b}}$ - Tube well away solid waste

WHO Std. - WHO Drinking Water Guidelines

DO - Dissolved Oxygen

BOD - Biochemical Oxygen Demand

COD - Chemical Oxygen Demand

In these results, the $\mathrm{pH}$ of different ground water samples near the dumping site was ranged from 7.2 to 8.1, which were within the standard limit. The total hardness in tube well varied from 510 to $530 \mathrm{mg} / \mathrm{l}$ as 
$\mathrm{CaCO}_{3}$ which were above the standard limit. In the same way, chloride, dissolved solids, iron and turbidity were above the standard limit.

Therefore, in these results, tube wells are not satisfactory as it is contaminated, especially, hardness, dissolved solid, conductivity and iron.

\section{A. Leach ate Analysis Results}

To compare leach ate results, a gallon of leach ate sample is taken from Htein Pin Final Disposal Site. Then, it is sent to ISO Tech laboratory to test leach ate results. Leach ate chemical analysis results are expressed as the above table. According to leach ate results in 2010, TS, SS, BOD and COD results are higher than 2007. This means that pollution is higher in this final disposal site than in earlier. In 2018, these results were less than the other two results. Because, YCDC improvement of disposal system, the method involves a bulldozer spreading and compacting the waste and a scraper is used to haul the cover material at the end of the day's operation. It made to install drainage ditches to divert surface water runoff from the surrounding and the surface of the landfill. The following table is the composition of leachate analysis results.

TABLE II. COMPARISON OF LEACHATE ANALYSIS RESULTS

\begin{tabular}{|c|c|c|c|c|c|}
\hline \multirow{2}{*}{ Sr. } & \multirow{2}{*}{ Parameters } & \multicolumn{2}{|c|}{ Leach ate Results } & ASEAN \\
\cline { 3 - 6 } & & $\mathbf{2 0 0 7}$ & $\mathbf{2 0 1 0}$ & $\mathbf{2 0 1 8}$ & Standard \\
\hline 1 & TS (mg/l) & 5810 & 5540 & 1888 & 720 \\
\hline 2 & SS (mg/l) & 1560 & 1290 & 68 & 100 \\
\hline 3 & BOD $(\mathrm{mg} / \mathrm{l})$ & 593 & 611 & 36 & 110 \\
\hline 4 & $\mathrm{COD}(\mathrm{mg} / \mathrm{l})$ & 120 & 135 & 96 & 250 \\
\hline
\end{tabular}

Note: TS - Total Solids

SS - Total Suspended Solids

BOD - Biochemical Oxygen Demand

COD - Chemical Oxygen Demand

\section{Conclusion}

Htein Pin open dumping site was found in tube wells are above the standard limit of physical and chemical parameters. As a result, there is a need of integrated municipal solid waste management of dumping site to prevent water contamination and the regular monitoring of the water sources nearby landfill dumping site is also required.

\section{REFERENCES}

1. Miezah K, Obiri-Danso K, Kadar Z, Fei-Baffoe B, Mensah MY, 2015 "Municipal Solid Waste Characterization and quantification as a measure towards effective waste management in Ghana."

2. Tchobaraglous, G, H. Theisen, and S. Vigil, 1993 "Integrated Solid Waste Management," New York, McGraw-Hill.

3. Dr. B. C. Purimla, "Environmental Engineering 2, Wastewater Engineering."

4. Duggal K. N, 1971 "Elements of Public Health Engineering."

5. TinPhyoHlaing, 2011 "Determination of solid waste composition in Mayan gone Township."

6. "Mackenzie L. Davis, David A. Cornwell, "Introduction to Environmental Engineering." 